\title{
Fundamentals of Operating Systems
}




\section{Macmillan Computer Science Series}

\section{Consulting Editor}

Professor F. H. Sumner, University of Manchester

S.T. Allworth, Introduction to Real-Time Software Design

Ian O. Angell, A Practical Introduction to Computer Graphics

Ian O. Angell and G. H. Griffith, High Resolution Graphics Using Fortran 77

R.E. Berry and B.A.E. Meekings, $A$ Book on $C$

G.M. Birtwistle, Discrete Event Modelling on Simula

T.B. Boffey, Graph Theory in Operations Research

Richard Bornat, Understanding and Writing Compilers

J.K. Buckle, Software Configuration Management

W.D. Burnham and A.R. Hall, Prolog Programming and Applications

J.C. Cluley, Interfacing to Microprocessors

Robert Cole, Computer Communications, second edition

Derek Coleman, A Structured Programming Approach to Data*

Andrew J.T. Colin, Fundamentals of Computer Science

Andrew J.T. Colin, Programming and Problem-solving in Algol 68*

S.M. Deen, Fundamentals of Data Base Systems*

S.M. Deen, Principles and Practice of Database Systems

P.M. Dew and K.R. James, Introduction to Numerical Computation in Pascal

M.R.M. Dunsmuir and G.J. Davies, Programming the UNIX System

K.C.E. Gee, Introduction to Local Area Computer Networks

J.B. Gosling, Design of Arithmetic Units for Digital Computers

Roger Hutty, Fortran for Students

Roger Hutty, Z80 Assembly Language Programming for Students

Roland N. Ibbett, The Architecture of High Performance Computers

Patrick Jaulent, The 68000 - Hardware and Software

J.M. King and J.P. Pardoe, Program Design Using JSP - A Practical Introduction

H. Kopetz, Software Reliability

E.V. Krishnamurthy, Introductory Theory of Computer Science

V.P. Lane, Security of Computer Based Information Systems

Graham Lee, From Hardware to Software - an introduction to computers

A.M. Lister, Fundamentals of Operating Systems, third edition*

G.P. McKeown and V.J. Rayward-Smith, Mathematics for Computing

Brian Meek, Fortran, $P L / 1$ and the Algols

Barry Morrell and Peter Whittle, $C P / M 80$ Programmer's Guide

Derrick Morris, System Programming Based on the PDPII

Pim Oets, MS-DOS and PC-DOS - A Practical Guide

Christian Queinnec, LISP

John Race, Case Studies in Systems Analysis

W.P. Salman, O. Tisserand and B. Toulout, FORTH

L.E. Scales, Introduction to Non-linear Optimization

Peter S. Sell, Expert Systems - A Practical Introduction

Colin J. Theaker and Graham R. Brookes, A Practical Course on Operating Systems

J-M. Trio, 8086-8088 Architecture and Programming

M.J. Usher, Information Theory for Information Technologists

B.S. Walker, Understanding Microprocessors

Peter J.L. Wallis, Portable Programming

I.R. Wilson and A.M. Addyman, A Practical Introduction to Pascal - with BS6192, second edition 


\section{Fundamentals of Operating Systems}

A. M. Lister

University of Queensland

Third Edition

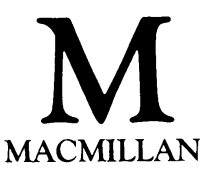


(C) A.M. Lister $1975,1979,1984$

All rights reserved. No reproduction, copy or transmission of this publication may be made without written permission.

No paragraph of this publication may be reproduced, copied or transmitted save with written permission or in accordance with the provisions of the Copyright Act 1956 (as amended).

Any person who does any unauthorised act in relation to this publication may be liable to criminal prosecution and civil claims for damages.

First edition 1975

Reprinted 1977, 1978

Second edition 1979

Reprinted 1980 (twice), 1981 (four times), 1982, 1983 (three times)

Third edition 1984

Reprinted 1984, 1985, 1986

Published by

MACMILLAN EDUCATION LTD

Houndmills, Basingstoke, Hampshire RG21 2XS

and London

Companies and representatives

throughout the world

British Library Cataloguing in Publication Data

Lister, A. M.

Fundamentals of operating systems. - 3 rd ed.

1. Operating systems (Computers)

I. Title

$001.64^{\prime} 25 \quad$ QA76.6

ISBN 978-0-333-37098-8

ISBN 978-1-349-17540-6 (eBook)

DOI 10.1007/978-1-349-17540-6 
to my parents 


\section{Contents}

Preface to the First Edition $\quad x i$

Preface to the Second Edition xii

Preface to the Third Edition xiii

1 Introduction 1

1.1 Types of operating system 3

1.2 The 'paper' operating system 5

2 Functions and Characteristics of an Operating System $\quad 7$

$\begin{array}{ll}2.1 \text { Operating system functions } & 7\end{array}$

$\begin{array}{ll}2.2 \text { Operating system characteristics } & 10\end{array}$

$\begin{array}{ll}2.3 \text { Desirable features } & 11\end{array}$

3 Concurrent Processes 13

3.1 Programs, processes, and processors 13

3.2 Communication between processes 15

$\begin{array}{ll}3.3 \text { Semaphores } & 17\end{array}$

3.4 Monitors $\quad 24$

$\begin{array}{ll}3.5 \text { Summary } & 26\end{array}$

4 The System Nucleus $\quad 27$

4.1 Essential hardware facilities $\quad 27$

$\begin{array}{ll}4.2 \text { Outline of the nucleus } & 29\end{array}$

$\begin{array}{ll}4.3 \text { Representation of processes } & 30\end{array}$

$\begin{array}{ll}\text { 4.4 The first-level interrupt handler } & 31\end{array}$

$\begin{array}{ll}4.5 \text { The dispatcher } & 34\end{array}$

4.6 Implementation of wait and signal 37

5 Memory Management $\quad 42$

$\begin{array}{ll}5.1 \text { Objectives } & 42\end{array}$

5.2 Virtual memory $\quad 44$

5.3 Implementation of virtual memory 45

5.4 Memory allocation policies $\quad 54$ 
viii

$\begin{array}{ll}5.5 \text { The working set model } & 60\end{array}$

$\begin{array}{ll}5.6 \text { Implementation in the paper system } & 62\end{array}$

6 Input and Output $\quad 63$

6.1 Design objectives and implications $\quad 64$

6.2 The I/O procedures 66

6.3 The device handlers $\quad 69$

$\begin{array}{ll}6.4 \text { Buffering } & 71\end{array}$

6.5 File devices $\quad 72$

$\begin{array}{ll}\text { 6.6 Spooling } & 74\end{array}$

$\begin{array}{ll}6.7 \text { Conclusion } & 76\end{array}$

7 The Filing System $\quad 77$

$\begin{array}{ll}7.1 \text { Objectives } & 77\end{array}$

$\begin{array}{ll}7.2 \text { File directories } & 78\end{array}$

$\begin{array}{ll}7.3 \text { Sharing and security } & 80\end{array}$

$\begin{array}{ll}7.4 \text { Secondary memory organisation } & 82\end{array}$

$\begin{array}{ll}7.5 \text { File system integrity } & 87\end{array}$

7.6 Opening and closing files $\quad 88$

$\begin{array}{ll}7.7 \text { Conclusion } & 92\end{array}$

8 Resource Allocation and Scheduling 93

$\begin{array}{ll}\text { 8.1 General observations } & 93\end{array}$

8.2 Allocation mechanisms $\quad 94$

$\begin{array}{ll}8.3 \text { Deadlock } & 96\end{array}$

$\begin{array}{ll}8.4 \text { The scheduler } & 101\end{array}$

$\begin{array}{ll}8.5 \text { Scheduling algorithms } & 104\end{array}$

$\begin{array}{ll}8.6 \text { Process hierarchies } & 108\end{array}$

8.7 Control and accounting $\quad 111$

$\begin{array}{ll}8.8 \text { Summary } & 115\end{array}$

9 Protection $\quad 116$

$\begin{array}{ll}9.1 \text { Motivation } & 116\end{array}$

$\begin{array}{ll}\text { 9.2 Development of protection mechanisms } & 117\end{array}$

$\begin{array}{ll}\text { 9.3 A hierarchical protection system } & 120\end{array}$

$\begin{array}{ll}9.4 \text { General systems } & 122\end{array}$

$\begin{array}{ll}9.5 \text { Conclusion } & 127\end{array}$

10 Reliability 128

$\begin{array}{ll}10.1 \text { Objectives and terminology } & 128\end{array}$

$\begin{array}{ll}10.2 \text { Fault avoidance } & 130\end{array}$

$\begin{array}{ll}10.3 \text { Error detection } & 133\end{array}$ 
$\begin{array}{lll}10.4 & \text { Fault treatment } & 134\end{array}$

$\begin{array}{ll}10.5 \text { Error recovery } & 135\end{array}$

$\begin{array}{ll}10.6 \text { Multilevel error handling } & 138\end{array}$

10.7 Conclusion $\quad 139$

11 Job Control $\quad 140$

$\begin{array}{ll}\text { 11.1 Some general remarks } & 140\end{array}$

$\begin{array}{ll}11.2 \text { Command languages } & 142\end{array}$

$\begin{array}{ll}11.3 \text { Job control languages } & 142\end{array}$

$\begin{array}{ll}11.4 \text { The job pool } & 145\end{array}$

$\begin{array}{ll}11.5 \text { System messages } & 146\end{array}$

11.6 Passage of a job through the system 146

$\begin{array}{ll}\text { Conclusion } & 148\end{array}$

Appendix: Monitors $\quad 152$

$\begin{array}{ll}\text { References } & 154\end{array}$

$\begin{array}{ll}\text { Index } & 158\end{array}$ 


\section{Preface to the First Edition}

An operating system is probably the most important part of the body of software which goes with any modern computer system. Its importance is reflected in the large amount of manpower usually invested in its construction, and in the mystique by which it is often surrounded. To the non-expert the design and construction of operating systems has often appeared an activity impenetrable to those who do not practise it. I hope this book will go some way toward dispelling the mystique, and encourage a greater general understanding of the principles on which operating systems are constructed.

The material in the book is based on a course of lectures I have given for the past few years to undergraduate students of computer science. The book is therefore a suitable introduction to operating systems for students who have a basic grounding in computer science, or for people who have worked with computers for some time. Ideally the reader should have a knowledge of programming and be familiar with general machine architecture, common data structures such as lists and trees, and the functions of system software such as compilers, loaders, and editors. It will also be helpful if he has had some experience of using a large operating system, seeing it, as it were, from the outside.

The first two chapters of the book define the functions of an operating system and describe some common operating system characteristics. Chapter 3 establishes the process as a basic concept in the discussion of the concurrent activities which go on inside an operating system, and describes how processes communicate with each other. The rest of the book then describes the construction of an operating system from the bottom up, starting at the interface with the machine hardware and ending at the interface with the user. By the end of the book the system which has been constructed is seen to possess the features demanded at the beginning.

Throughout the book I have tried to show how each stage in the construction of an operating system naturally follows on the previous ones, and have emphasised the logical structure of the system as a whole. I have done this for two reasons. The first is pedagogical: my experience indicates that students gain a better understanding of complex material if it is presented in a coherent manner. The second is frankly polemic: this is the way I believe operating systems should be built. Attention to structure and logical dependence are the 
best means we have of building operating systems which are easy to understand, easy to maintain, and relatively error free.

Finally, I would like to thank the many friends and colleagues who have helped in the writing of this book. In particular I would like to thank David Lyons, who has been a fertile source of ideas and comment; and David Howarth, who made valuable comments on an earlier draft. Thanks are also due to Colin Strutt, Morris Sloman, John Forecast, Ron Bushell and Bill Hart, who have made constructive suggestions for improving the text.

ANDREW LISTER

\section{Preface to the Second Edition}

Any book on computer science suffers from the fact that its subject matter is undergoing rapid change, both technological and conceptual. A book on operating systems is no exception: the hardware on which systems run is being revolutionised by the large scale integration of components, and ideas about what operating systems should do are being modified by changing user requirements and expectations. Although this book is about 'fundamentals', which can be expected to be less volatile than other topics, it would be foolish to ignore the developments which have occurred in the four years since publication.

Consequently I have amended the text in three main ways for this edition. First, there is an additional chapter on reliability, a topic whose importance has increased dramatically as reliance on computer systems has grown in many areas of life. Secondly, the references to real-life operating systems have been updated to include systems which have come into use since the first edition, and references to the literature have been similarly updated. Thirdly, I have altered the presentation of certain topics so as better to reflect current ideas, and have expanded the conclusion to indicate what developments can be expected in the future.

Other changes in the text have been motivated by feedback from readers of the first edition. Here I owe a great debt to my students, who have had the perception to point out errors, and the good sense to expose inadequate exposition. Any improvements in this respect are due largely to them, though any remaining inadequacies are, of course, my own. 


\title{
Preface to the Third Edition
}

\begin{abstract}
Almost a decade after publication it is reassuring to know that the 'fundamentals' of the title remain essentially the same. However, as the systems of the early 1970s fade into distant memory I have found it necessary to update the text by reference to their successors. I have also taken the opportunity to introduce one or two new topics, and to improve the presentation of several others. In this latter respect I am indebted to Morris Sloman and Dirk Vermeir for their valuable suggestions, and, as ever, to my students.
\end{abstract}

